\title{
Hydrogeologic-Setting Classification for Suffolk County, Long Island, New York with Results of Selected Aquifer-Test Analyses
}

By Richard A. Cartwright

U.S. GEOLOGICAL SURVEY

Open-File Report 96-457

Prepared in cooperation with the

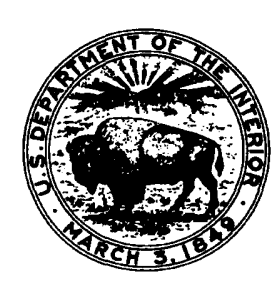

SUFFOLK COUNTY WATER AUTHORITY

SUFFOLK COUNTY DEPARTMENT OF HEALTH SERVICES 


\title{
U.S. DEPARTMENT OF THE INTERIOR BRUCE BABBITT, Secretary
}

\author{
U.S. GEOLOGICAL SURVEY
}

Gordon P. Eaton, Director

For additional information write to:

U.S. Geological Survey 2045 Route 112, Bldg. 4 Coram, NY 11727
Copies of this report may be purchased from:

U.S. Geological Survey

Branch of Information Services

P.O. Box 25286

Denver, CO 80225-0286 


\section{CONTENTS}

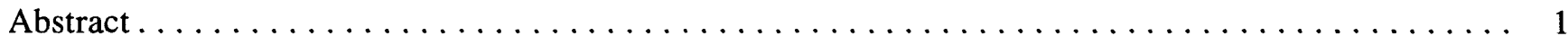

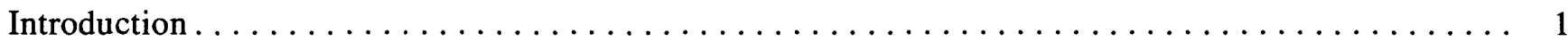

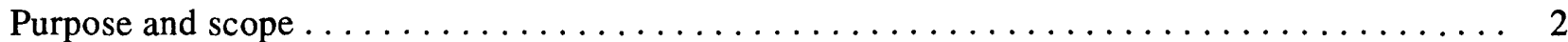

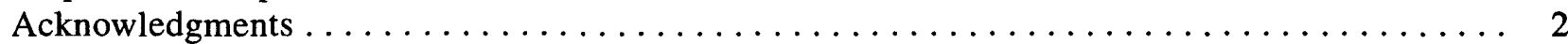

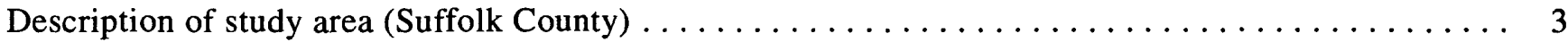

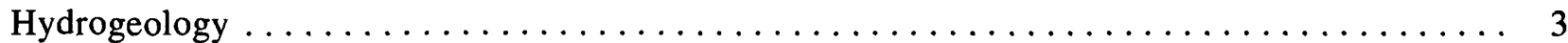

Ground-water use $\ldots \ldots \ldots \ldots \ldots \ldots \ldots \ldots \ldots \ldots \ldots \ldots \ldots \ldots \ldots \ldots \ldots$

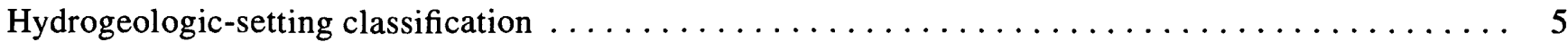

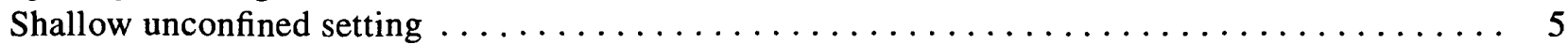

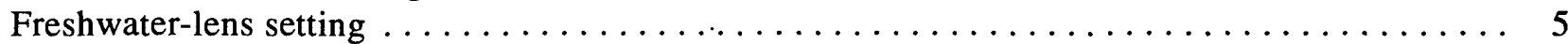

Shallow confined setting $\ldots \ldots \ldots \ldots \ldots \ldots \ldots \ldots \ldots \ldots \ldots \ldots \ldots \ldots \ldots \ldots$

South-shore confined setting $\ldots \ldots \ldots \ldots \ldots \ldots \ldots \ldots \ldots \ldots \ldots \ldots \ldots \ldots \ldots \ldots \ldots \ldots$

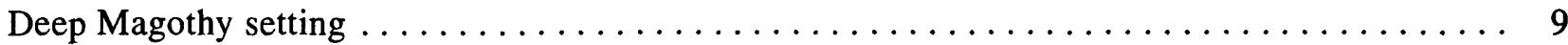

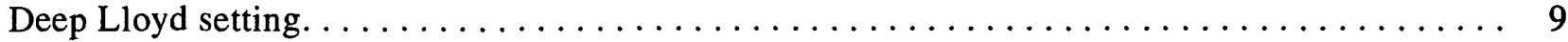

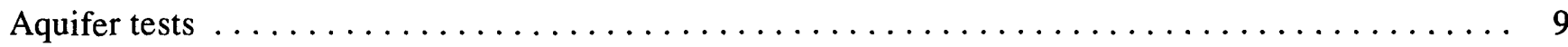

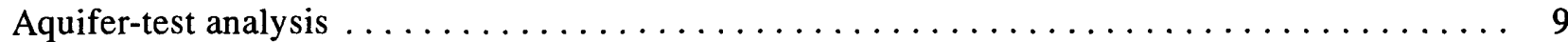

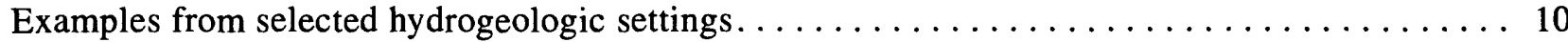

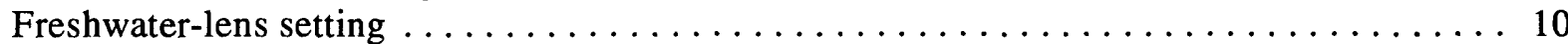

Local hydrogeology $\ldots \ldots \ldots \ldots \ldots \ldots \ldots \ldots \ldots \ldots \ldots \ldots \ldots \ldots$

Upper glacial aquifer test $\ldots \ldots \ldots \ldots \ldots \ldots \ldots \ldots \ldots \ldots \ldots \ldots \ldots \ldots \ldots$

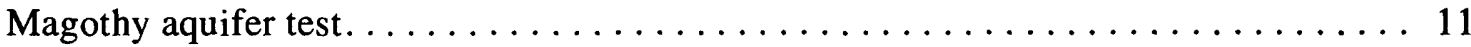

South-shore confined setting $\ldots \ldots \ldots \ldots \ldots \ldots \ldots \ldots \ldots \ldots \ldots \ldots \ldots \ldots \ldots \ldots \ldots \ldots \ldots$

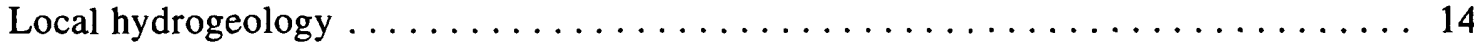

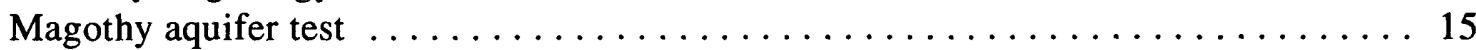

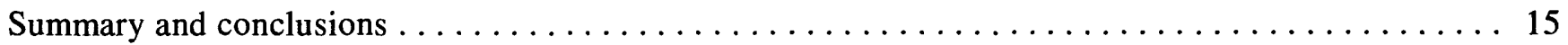

References cited. ................................... 17

FIGURES

1. Map showing location and principal geographic features of Suffolk County,

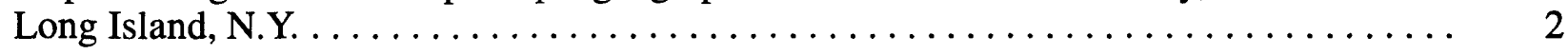

2. Generalized hydrogeologic section of Long Island, N.Y.. . . . . . . . . . . . . . 3

3. Map of Long Island, N.Y., showing Suffolk County Water Authority service areas . . . . . 4

4. Map showing hydrogeologic setting locations, Suffolk County, N.Y.:

A. Shallow unconfined, shallow confined, and deep confined (Lloyd). . . . . . . . . . 6

B. South-shore confined, deep confined (Magothy), and freshwater lens . . . . . . . . . 6

5. Generalized geologic section of Long Island, N.Y., indicating hydrogeologic settings:

A. Shallow unconfined, shallow confined, and deep confined (Lloyd) . . . . . . . . . . 7

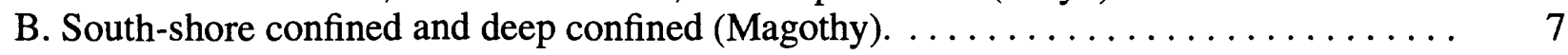

C. Freshwater lens $\ldots \ldots \ldots \ldots \ldots \ldots \ldots \ldots \ldots \ldots \ldots \ldots \ldots \ldots \ldots \ldots \ldots \ldots$

6. Generalized hydrologic section of South Fork of Long Island, N.Y., showing hydrologic units, freshwater lens, and ground-water-flow patterns typical of area near Long Springs

Road pumping center

7. Plan view and vertical section showing upper glacial aquifer-test setup at Long Springs Road pumping center, Southampton, N.Y. . 
FIGURES (continued)

8. Plan view and vertical section showing Magothy aquifer-test setup at Long Springs Road

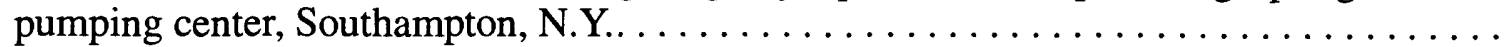

9. Generalized hydrologic section of the Bay Shore area of Long Island, N.Y., showing hydrologic units, freshwater/saltwater interface, and typical ground-water-flow patterns . . . . . . . . 14

10. Plan view and vertical section showing Magothy aquifer-test setup at Thomas Street pumping center, Bay Shore, N.Y.

\section{CONVERSION FACTORS, ABBREVIATIONS, AND VERTICAL DATUM}

\begin{tabular}{lll}
\multicolumn{1}{c}{ Multiply } & By & To Obtain \\
& Length & \\
inch (in.) & 2.54 & centimeter \\
foot (ft) & 0.3048 & meter \\
& Area & \\
square mile ( $\left.\mathrm{mi}^{2}\right)$ & 2.59 & square kilometer \\
& Hydraulic Conductivity & \\
& & \\
feet per day (ft/d) & & meters per day
\end{tabular}

Sea level: In this report, "sea level" refers to the National Geodetic Vertical Datum of 1929 (NGVD of 1929)--a geodetic datum derived from a general adjustment of the first-order level nets of the United States and Canada. formerly called Sea Level Datum of 1929. 


\title{
Hydrogeologic-Setting Classification for Suffolk County, Long Island, New York, with Results of Selected Aquifer-Test Analyses
}

\author{
By Richard A. Cartwright
}

\section{Abstract}

Suffolk County was divided into six hydrogeologic settings such that the aquifer properties and, thus, ground-water movement and response to pumping stresses, would be relatively uniform within each setting. This approach could facilitate (1) siting of municipal wells to minimize salt-water intrusion, and (2) estimation of the ground-water-contributing areas of municipal wells to prevent aquifer contamination. Aquifer tests were performed in two hydrogeologic settings-a freshwater lens on the South Fork (a confined-aquifer and an unconfined-aquifer test) and a south-shore setting in western Suffolk County (confinedaquifer test only). Data from the two tests were analyzed through analytical and graphical techniques to yield preliminary hydraulic values, and these values were used as initial input for a radial-flow-model analysis. The model-generated horizontal hydraulic conductivity values obtained for the individual sites were within the range of values documented in the literature for the given aquifer at the nearest possible site. Additional aquifer tests in hydrogeologic settings that lack sufficient data could further refine the applicability of this technique within Suffolk County.

\section{Introduction}

Ground water is the sole source of freshwater in Suffolk County, on Long Island, N.Y. (fig. 1). The county's growing population of 1.33 million (Long Island Lighting Company, 1995) requires everincreasing amounts of water. One result of increased ground-water withdrawals is an increase in the amount of water that is discharged as treated wastewater to the surrounding saltwater bodies and not returned to the aquifer system; this causes a decline in the water table and an attendant decrease in streamflow. The water table also can be lowered wherever industrial or residential development creates impervious surfaces that prevent the infiltration of precipitation to the aquifer system. The effects of water-table declines and of other results of urbanization on Long Island's ground-water system are documented in several sources, including Buxton and others (1981), Sulam (1979), Pluhowski and Spinello (1978), Garber and Sulam (1976), and Franke (1968).

The difficulty of supplying adequate quantities of potable ground water in an area of increasing population and decreasing recharge is compounded by the potentially adverse effects of pumping, such as (1) the alteration or reversal of natural flow gradients, which can induce the migration of contaminated water into uncontaminated parts of the ground-water reservoir; (2) upconing and (or) landward migration of saltwater, especially in nearshore areas; and (3) reduction of streamflow and the natural outflow of freshwater to the surrounding saltwater bodies, which can adversely affect their economic, ecologic, esthetic, and recreational benefits.

Strategies and procedures to avoid excessive ground-water withdrawals could be developed if the areas that contribute water to each pumping well could be delineated; this would define the areas affected by pumping and would allow estimation of maximum withdrawal rates that would not cause the adverse effects listed above. Because Long Island's ground-water reservoir is a large, multiaquifer system whose lithology and stratigraphy differ from place to place, development of ground-water-protection strategies will require site-specific data on hydrogeologic conditions at the pumping centers of concern. 
The U.S. Geological Survey (USGS), in cooperation with the Suffolk County Water Authority (SCWA) and the Suffolk County Department of Health Services (SCDHS), conducted a study to (1) categorize Suffolk County's ground-water system into a series of hydrogeologic settings that, together, represent the types and range of conditions in Suffolk County for use in siting public-supply wells; (2) document the range of values of hydraulic properties within each of these settings, and (3) perform controlled aquifer tests in two different hydrogeologic settings as examples of how to obtain data for use in delineating ground-water-contributing areas of a pumped well.

Six settings were identified, each typifying a different hydrogeologic framework, on the premise that the response to pumping stress within a given part of each setting would be similar to the response in all other parts of the same setting. This categorization provides a basis from which any location's suitability for well installation can be inferred and, thus, could minimize the number of aquifer tests needed to identify appropriate future pumping sites .
Two sites were chosen for controlled aquifer tests to obtain data for comparison with published values-one is at a pumping station at Long Springs Road in Southampton, on the South Fork, and the other at a pumping station at Thomas Street near Bay Shore, in western Suffolk County (fig. 1). These sites were selected because extensive data on hydrogeologic conditions and well design were available.

\section{Purpose and Scope}

This report (1) describes the six hydrogeologic settings identified in Suffolk County, (2) summarizes the hydraulic properties within each of these settings, and (3) presents results of the aquifer tests along with previously published values for the respective areas.

\section{Acknowledgments}

Thanks are extended to the SCDHS staff for monitoring-well installation and water-quality analyses. The SCWA helped during the planning stages of monitoring-well placements and during the aquifer tests.

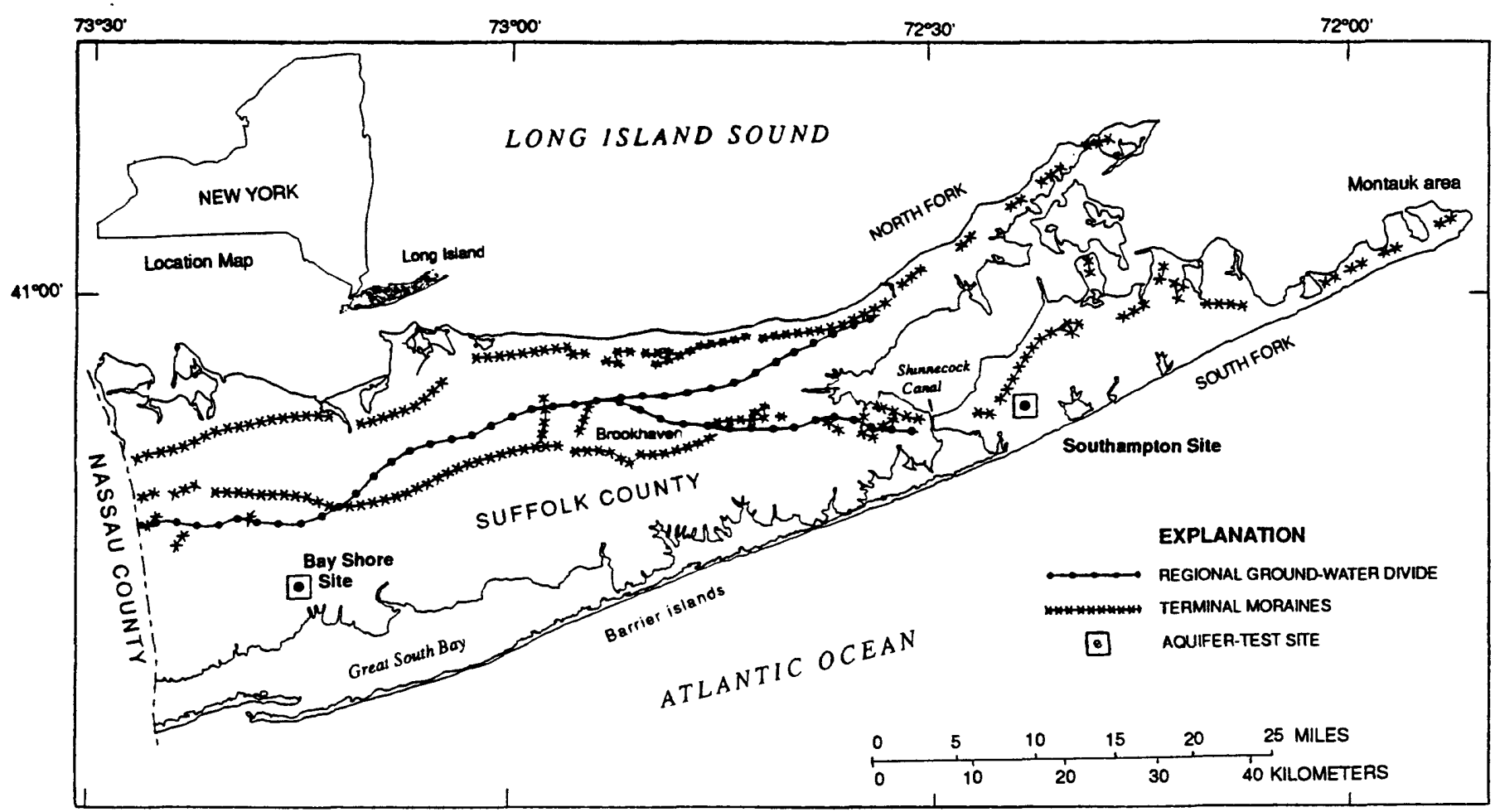

Figure 1. Location and principal geographic features of Suffolk County, Long Island, N.Y. (Modified from Eckhardt and others, 1989, fig. 1) 


\section{DESCRIPTION OF STUDY AREA (SUFFOLK COUNTY)}

The aquifer system in Suffolk County consists of a sequence of unconsolidated deposits overlying crystalline bedrock. The bedrock dips slightly to the southeast (fig. 2). Depth to bedrock ranges from $0 \mathrm{ft}$ at the northwestern shore to about $2,700 \mathrm{ft}$ beneath the south-shore barrier islands.

The unconsolidated units, in descending order, are the Pleistocene-aged glacial deposits, which form the upper glacial aquifer and the Gardiners Clay, the Cretaceous-aged fluvial and deltaic Magothy aquifer, the Raritan confining unit (hereafter referred to as the Raritan clay), and the Lloyd sand aquifer. Characteristics of each of these units are discussed in McClymonds and Franke (1972); further details are given in Fuller (1914), Suter and others (1949), and in many more recent reports on specific areas of Long Island.

\section{Hydrogeology}

All of Long Island's ground-water reserves originate as precipitation (fig. 2). Average precipitation amounts range from about $42 \mathrm{in} / \mathrm{yr}$ near the shores to $50 \mathrm{in} / \mathrm{yr}$ in north-central Suffolk County at higher altitudes. The islandwide average is about $44 \mathrm{in} / \mathrm{yr}$ (Miller and Frederick, 1969). Roughly half of this amount (22-23 in/yr) becomes recharge (Franke and McClymonds, 1972); the other half is lost as runoff and through evapotranspiration.

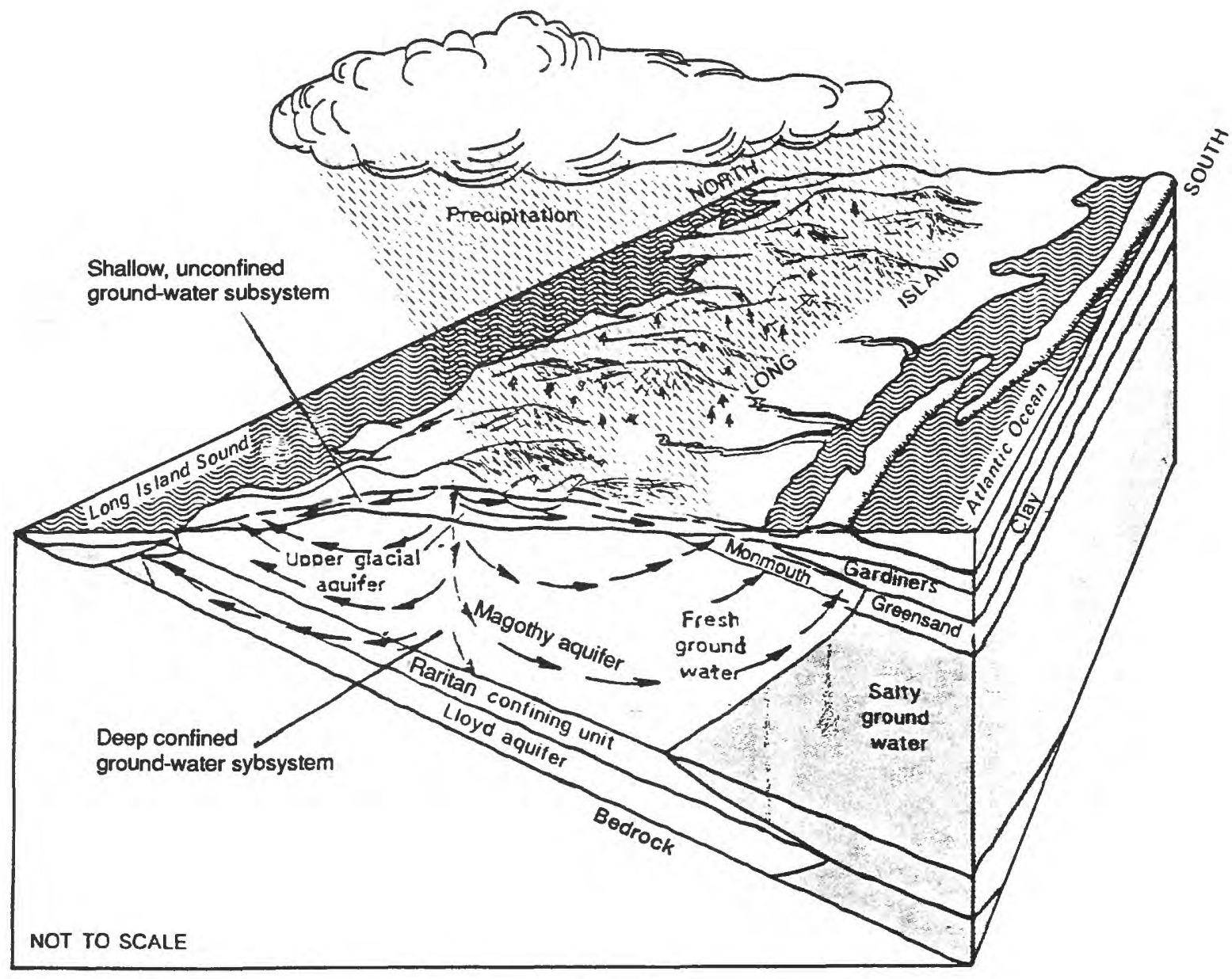

Figure 2. Generalized hydrogeologic section of Long Island, N.Y. (Modified from Nemickas and others, 1989, fig. 9.) 
Water entering the ground takes either of two general paths, depending on the location-it either stays in the shallow, unconfined subsystem (watertable aquifer) or moves into the deep, confined subsystem (fig. 2). Water in the shallow subsystem flows horizontally and discharges to streams or the shore and enters the Magothy aquifer only in the few locations at which Pleistocene deposits are absent. Water that reaches the water table north of the ground-water divide flows northward toward Long Island Sound, and water that reaches the water table south of the divide flows southward toward the southshore bays and the Atlantic Ocean; water entering the system at either location also can flow east or west from interstream divides toward an adjacent stream. Only the precipitation that falls near the center of the island passes through the shallow subsystem and continues into the deep, confined system (the Magothy, Raritan and Lloyd units) (fig. 2). A major difference between the two subsystems is the traveltime of water moving from its point of entry to a point of discharge. Franke and Cohen (1972) estimate that the time required for water in the shallow subsystem to move into an adjacent streambed can be from 25 to 30 years, whereas the time required for water in the Magothy and Lloyd aquifers to move southward from the entry point near the divide to beyond the barrier beaches is about 800 and 3,000 years, respectively.

\section{Ground-Water Use}

The SCWA and other private water-supply companies provide about 85 percent of Suffolk County's domestic water supply; individual private wells supply the remainder. Most of the pumping for public supply in Suffolk County is managed by the SCWA; their service areas are delineated in figure 3. Each pumping station operates one or more publicsupply wells. SCWA withdrew 56.8 billion gallons in 1995 from just over 400 wells to serve about 1.1 million people.

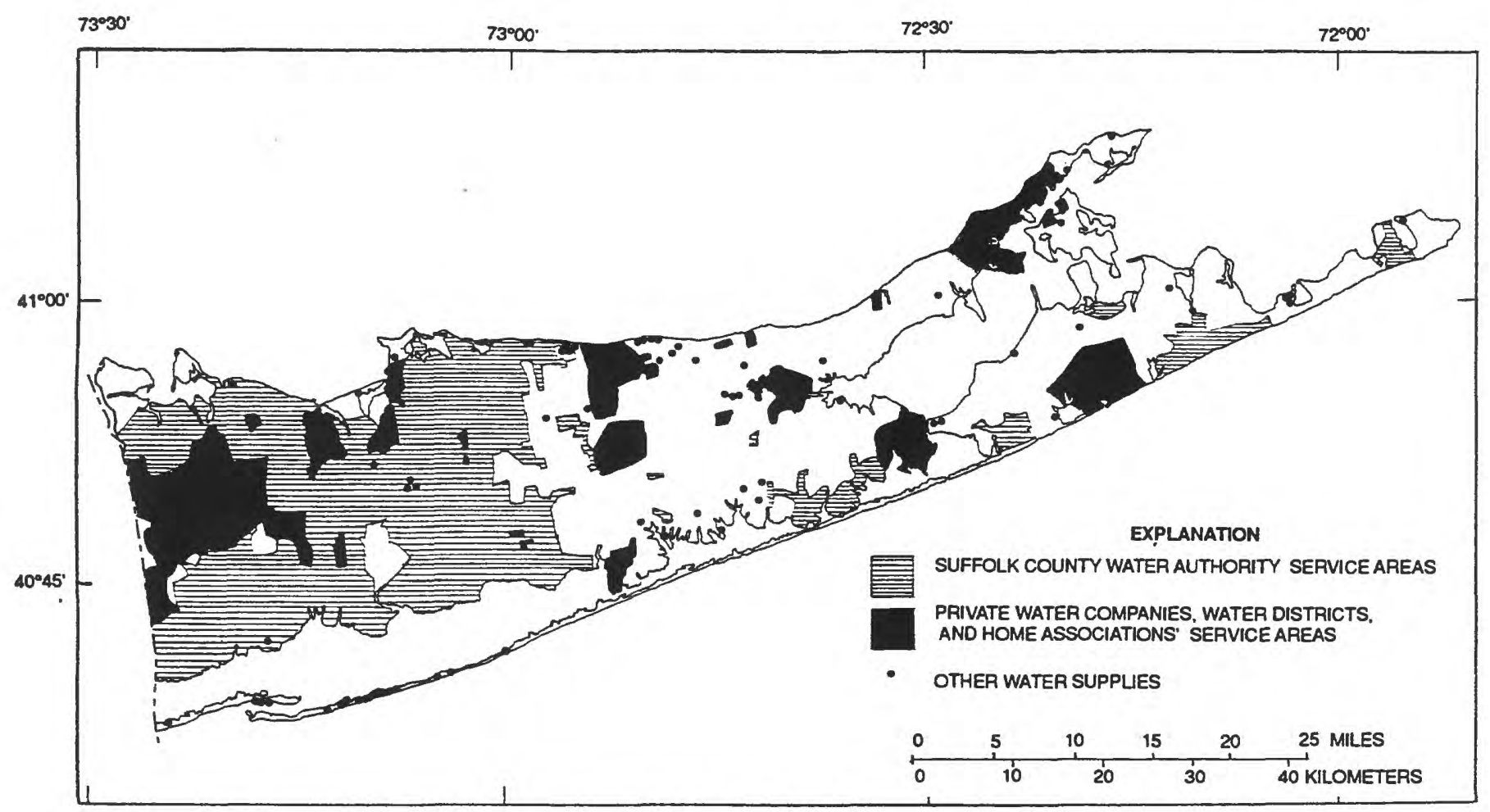

Figure 3. Suffolk County Water Authority service areas, Long Island, N.Y. (Data from Thomas J. Keenan, Suffolk County Department of Health Services, written commun., 1981.) 


\section{HYDROGEOLOGIC-SETTING CLASSIFICATION}

The Suffolk County aquifer system was divided into six hydrogeologic settings on the basis of general physiography, regional and local hydrogeology, and hydraulic characteristics. The six settings are: shallow unconfined; freshwater lens (unconfined, confined); shallow confined; southshore confined; deep Magothy confined; and Lloyd confined. These settings and their hydrogeologic relations are depicted in generalized maps and vertical sections in figures 4 and 5 , respectively. The six hydrogeologic settings presented herein encompass the range of conditions found at most wellfields in Suffolk County.

\section{Shallow Unconfined Setting}

The shallow unconfined setting (figs. 4A, 5A) is present throughout the main body of Suffolk County and represents relatively shallow, unconfined conditions, mainly in the upper glacial aquifer. Shallow, unconfined conditions are also found in areas where the upper glacial aquifer is thin and the Gardiners Clay is absent, and where the hydraulic characteristics of the Magothy aquifer are similar to those of the upper glacial aquifer. In these areas, the shallow unconfined setting includes the upper part of the Magothy. Although not classified separately in this study, an east-west band along the southern shore could possibly be included as a separate hydrogeologic setting because it contains most of the Island's streams.

Horizontal hydraulic conductivity values typical of the shallow unconfined setting, as derived from specific-capacity data obtained in western Suffolk County (McClymonds and Franke, 1972), range from $40 \mathrm{ft} / \mathrm{d}$ to $294 \mathrm{ft} / \mathrm{d}$ in the upper glacial aquifer, and from $57 \mathrm{ft} / \mathrm{d}$ to $160 \mathrm{ft} / \mathrm{d}$ in the Magothy aquifer. Ground water in the shallow unconfined setting is vulnerable to contamination from surface sources. The relatively high horizontal conductivity, the absence of confining units, and the discontinuous nature of clayey zones enhances the potential for contaminant migration.

\section{Freshwater-Lens Setting}

This hydrogeologic setting is restricted to the eastern forks of Long Island (figs.4B, 5C) and represents freshwater lenses that are bounded laterally and below by saltwater. The freshwater lenses are isolated from the rest of Long Island's fresh groundwater system and, therefore, have no adjacent freshwater source that could provide recharge. This type of setting is also found along the barrier islands of the southern shore, but they are not considered here because pumping for public supply there is negligible.

The freshwater-lens setting is characterized by unconfined conditions on the North and South Forks and includes two areas characterized by confined conditions in the central part of the South Fork (Nemickas and Koszalka, 1982) and the eastern (Montauk) part (Prince, 1986). Although the North Fork contains confined conditions locally, these areas were not considered in the study.

The North Fork contains a series of freshwater lenses, that generally decrease in thickness eastward. Thicknesses range from about $550 \mathrm{ft}$ (Bohn-Buxton and others, 1996) at the western end of the North Fork to about $90 \mathrm{ft}$ (McNew and Arav, 1995) near the eastern end and approach zero close to the shore. On the South Fork, the thickness of the freshwater lens has a maximum of about $600 \mathrm{ft}$ and approaches zero at the shores (Nemickas and Koszalka, 1982; Fetter, 1971). Under natural (nonpumping) conditions, the position of the freshwater/saltwater interface represents a relatively static balance of fluid pressures of the freshwater and the denser, underlying saltwater. The position of this interface can shift in response to changes in pumping and other hydrologic stresses.

The unconfined part of the freshwater lens setting is in the upper glacial aquifer, and the horizontal hydraulic conductivity ranges from 40 to $750 \mathrm{ft} / \mathrm{d}$ (Nemickas and Koszalka, 1982; Fetter, 1971). The confined part in the main body of the South Fork is in the Magothy aquifer, and the horizontal hydraulic conductivity ranges from to 30 to $135 \mathrm{ft} / \mathrm{d}$ (Fetter, 1971). The confined part on the Montauk peninsula is mainly in the upper glacial aquifer; here the horizontal hydraulic conductivity ranges from 130 to $350 \mathrm{ft} / \mathrm{d}$ (Prince, 1986).

Movement of the freshwater/saltwater interface results in a zone of diffusion, and excessive withdrawals from public-supply wells can cause upconing of saltwater and move the interface far enough inland to cause contamination of the freshwater supply. The other major source of groundwater degradation in this hydrogeologic setting is surface contaminants, especially pesticides and fertilizers used on the many farms in this area; Soren and 


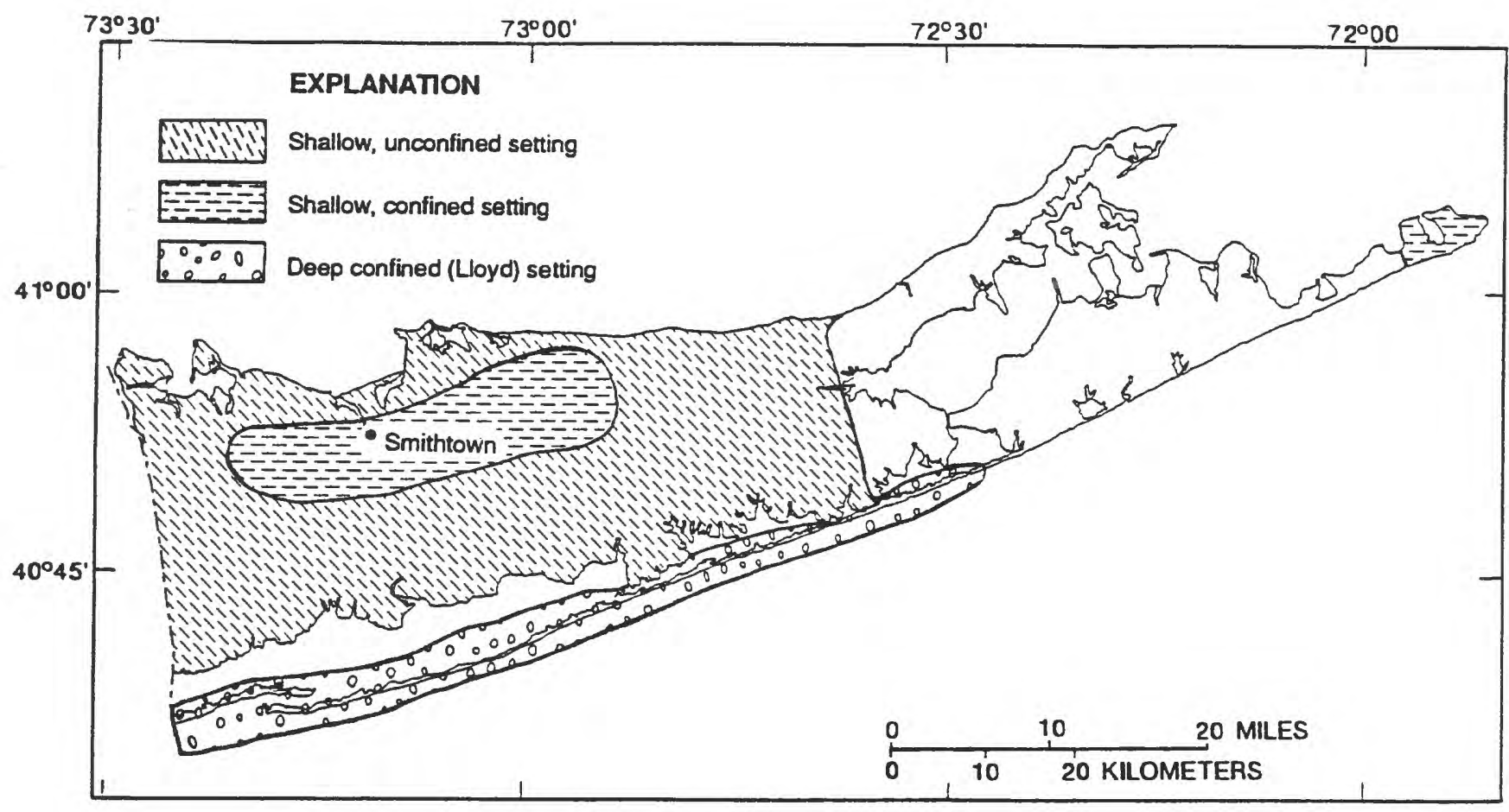

A

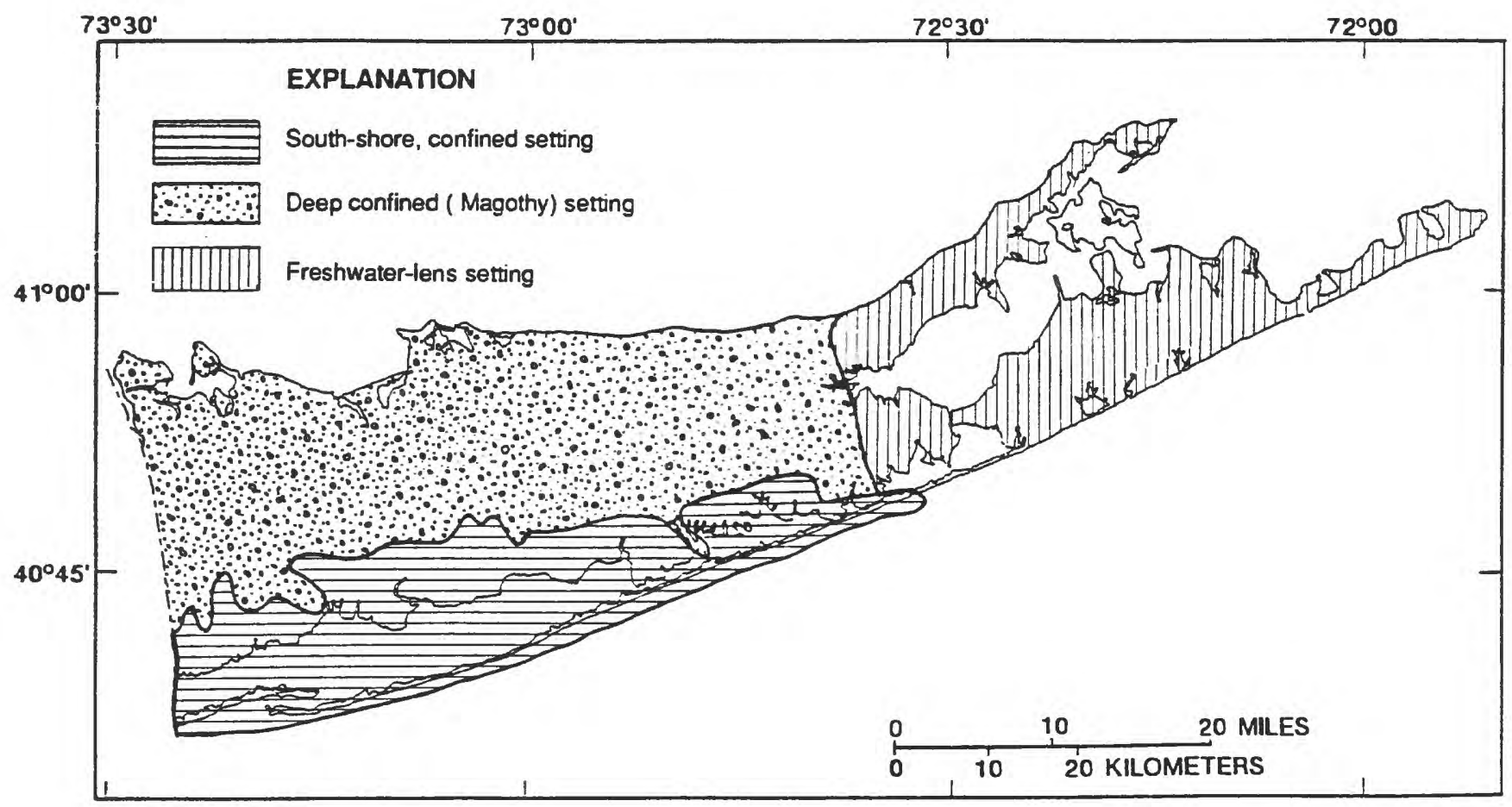

B

Figure 4. Locations of hydrogeologic settings, Suffolk County, N.Y.: A. Shallow unconfined, shallow confined, and deep confined (Lloyd) settings. B. South-shore confined, deep confined (Magothy), and freshwater-lens settings. 


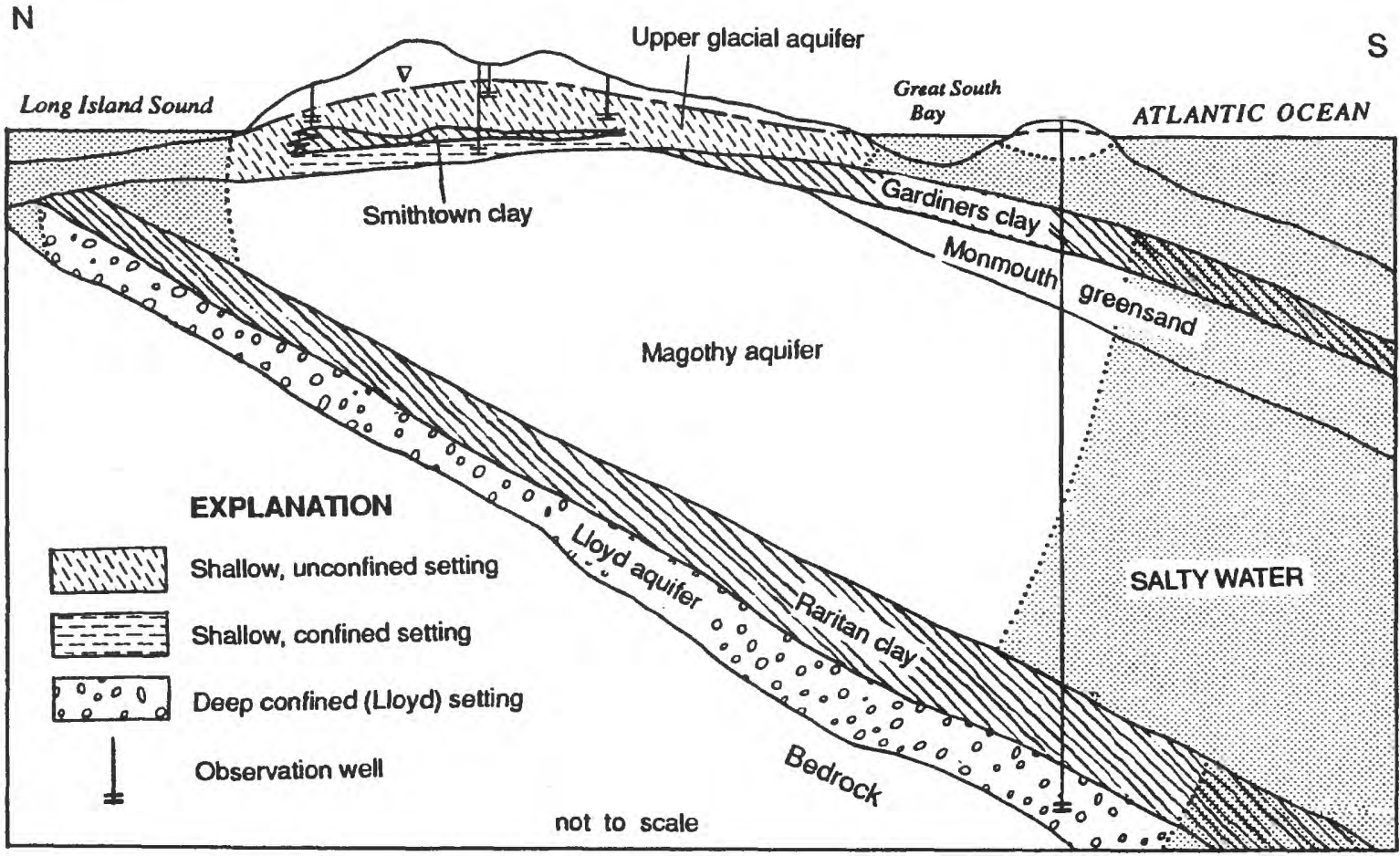

A

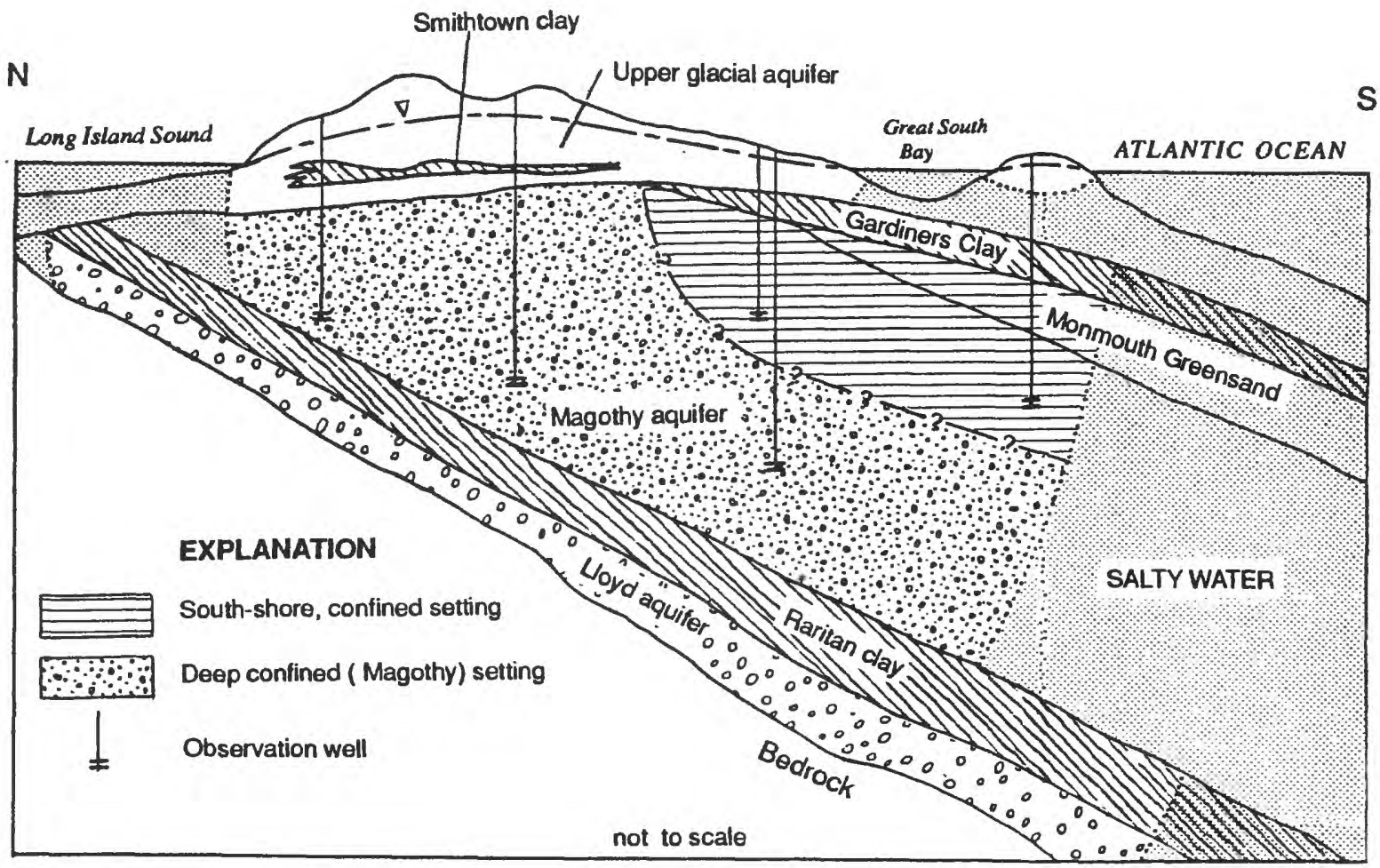

B

Figure 5. Generalized geologic section of Long Island, N.Y., indicating hydrogeologic settings: A. Shallow unconfined, shallow confined, and deep confined (Lloyd) settings. B. South-shore confined and deep confined (Magothy) settings. (Modified from Cohen and others, 1968, pl. 2C) 


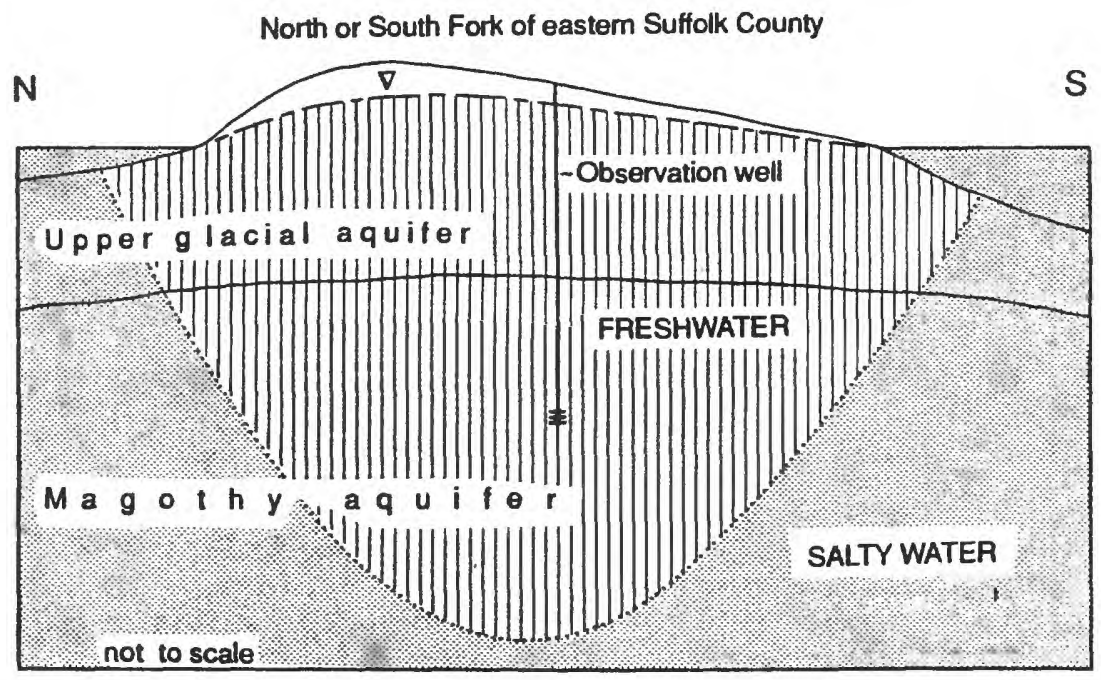

Figure 5. (continued). C. Generalized geologic section of eastern forks of Suffolk County, N.Y., indicating a freshwater lens.

Stelz (1984) cited widespread contamination by the highly toxic carbamate pesticide, aldicarb (trademark TEMIK, Union Carbide Corp. ${ }^{1}$ ) on the North and South Forks.

\section{Shallow Confined Setting}

This setting (roughly $90 \mathrm{mi}^{2}$ ), in north-central Suffolk County, is bounded on the north and south by moraines and represents that zone within the upper glacial aquifer that is confined by a lacustrine clay unit, the "Smithtown clay" (Krulikas and Koszalka, 1983). This unit, first documented by Lubke (1964), lies from 20 to $200 \mathrm{ft}$ below land surface and ranges from 20 to $170 \mathrm{ft}$ in thickness (figs. 4A, 5A). Other areas in Suffolk County could be classified locally as shallow and confined, but they represent mostly very small areas in which clay lenses create semiconfined conditions and, therefore, were not included.

Horizontal hydraulic conductivity of the upper glacial aquifer in western Suffolk County generally ranges from 40 to $295 \mathrm{ft} / \mathrm{d}$ (McClymonds and Franke, 1972). Lubke (1964) reports a value of $120 \mathrm{ft} / \mathrm{d}$ for this aquifer below the Smithtown clay. In this setting, the Smithtown clay generally acts as a barrier to the downward movement of surface contaminants.

\footnotetext{
1. Use of trade, product, or firm names in this publication is for descriptive purposes only and does not imply endorsement by the U.S.Government.
}

\section{South-Shore Confined Setting}

This setting represents an irregular, east-westtrending band 2 to $10 \mathrm{mi}$ wide along the southern shore in the upper part of the Magothy aquifer and Monmouth greensand (where present) where these units are confined by the Gardiners Clay. The band extends from the Nassau-Suffolk County line to the Shinnecock Canal area (fig. 1) and corresponds to the area where the Gardiners Clay has been delineated (figs. 4B, 5B). Roughly half of this area underlies the Great South Bay and extends south to the barrier islands. The Gardiners Clay is a marine deposit of probable Sangamon age (Soren, 1971) that contains less than 10 percent sand and silt beds (Doriski and Wilde-Katz, 1983). The unit generally is continuous along the southern shore; its thickness ranges from 0 to $90 \mathrm{ft}$ and increases to the south. Several northsouth-trending bands in which the Gardiners Clay is missing probably represent ancient stream channels that were eroded by glacial meltwater. The Gardiners Clay is generally considered to be an effective confining unit, even where it is only a few feet thick.

This setting differs in two ways from the shallow confined setting described previously-its aquifers are generally thicker, and the hydraulic conductivity is generally lower. Horizontal hydraulic conductivity of the upper part of the Magothy here and throughout Long Island is about $50 \mathrm{ft} / \mathrm{d}$.

Ground-water quality in the south-shore confined setting is threatened by (1) the potential for saltwater migration to nearshore production wells, 
and (2) possible downward movement of surfacederived contaminants from the upper glacial aquifer in areas where the Gardiners Clay is absent.

\section{Deep Magothy Setting}

This hydrogeologic setting extends throughout most of Long Island (figs. 4B, 5B), although it may be absent locally in the extreme northwestern part of Suffolk County. This setting is characterized by confined conditions created by numerous clayey and silty layers, and the degree of confinement increases with depth. Horizontal hydraulic conductivity ranges from 55 to $160 \mathrm{ft} / \mathrm{d}$ (McClymonds and Franke, 1972); a representative regional value of $70 \mathrm{ft} / \mathrm{d}$ was given by H.T. Buxton and D.A. Smolensky (U.S. Geological Survey, written commun., 1990). The deep Magothy setting has a potential for saltwater upconing and for contamination by downward movement of surface-derived contamination through the semiconfining units, as a result of heavy pumping.

\section{Deep Lloyd Setting}

This hydrogeologic setting is assigned only to the south-shore barrier islands (figs. $4 \mathrm{~A}, 5 \mathrm{~A}$ ), where the Lloyd aquifer is the only source of potable freshwater. The Lloyd is the deepest aquifer on Long Island and is confined by the Raritan clay.

Horizontal hydraulic conductivity ranges from 40 to $67 \mathrm{ft} / \mathrm{d}$ in Nassau and Queens Counties (Isbister, 1966; Lusczynski and Swarzenski, 1966; Franke and Cohen, 1972; Soren, 1971); the horizontal hydraulic conductivity at Brookhaven in central Suffolk County (fig. 1) is estimated to be $22 \mathrm{ft} / \mathrm{d}$ (Warren and others, 1968).

Water from the Lloyd aquifer commonly has undesirably high concentrations of iron (Soren, 1971). The aquifer is tightly confined by the overlying Raritan clay (which has a vertical conductivity of about $0.001 \mathrm{ft} / \mathrm{d}$; Franke and Cohen, 1972) and, therefore, is susceptible to rapid lateral head changes caused by pumping. This makes it more susceptible to saltwater intrusion than other Long Island aquifers. This setting is the deepest and, therefore, is the best protected from surface contaminants. Also, the hydraulic conductivity is lower than in other settings and provides a longer traveltime for ground water. Thus, the possibility of contamination from overlying units is not a major concern at present.

\section{AQUIFER TESTS}

Analysis of an aquifer's response to pumping requires estimation of values for several aquifer characteristics and definition of hydrologic boundaries. The type of hydrogeologic setting largely determines the approach to be taken in an aquifer-test analysis.

\section{Aquifer-Test Analysis}

Three techniques were used in this study to estimate hydraulic properties of the aquifersanalytical methods, curve-matching and graphical methods, and a numerical radial-flow model. Several methods can be used to evaluate data obtained from aquifer tests, depending on the conditions at each site. The methods examined in this study were:

(1) an analytical solution based on the Thiem equation (Bentall, 1963; Driscoll, 1986), corrected for partial penetration (Neuman, 1974);

(2) several curve-matching and graphical methods that use techniques by Theis (1935), Cooper (1963), Boulton (1963), Stallman (1965), Cooper and Jacob (1946); and

(3) a two-dimensional, finite-element radial-flow model (Reilly, 1984).

The analytical and curve-matching methods were used to obtain estimates of horizontal hydraulic conductivity, transmissivity, and storativity; these values were then used as input for the initial run of a numerical radial-flow model. This method of aquifer-test analysis is more time-consuming than the analytical and graphical methods but has advantages-whereas the analytical and graphical methods treat the aquifer as homogenous, address each monitoring well separately, and generally do not allow for partial penetration by pumping and monitoring wells, the radial-flow model allows for spatial variability in aquifer properties, solves for head at all monitoring points simultaneously, and allows pumping and monitoring wells to be screened at any interval.

The radial-flow model was used to simulate drawdown and recovery. Input data included (1) model geometry, (2) boundary conditions, (3) hydrogeologic characteristics, and (4) pumping rate. The model simulates radial flow in which the flow field is two dimensional and symmetric around a 
central axis. The model grid has a specific number of nodes and elements, and differing hydraulic conductivity values can be assigned to each element in the model grid. Areas in which precise results are desired (such as across the entire model grid at the depth of the screened zone, or at the depth of monitoring wells) are represented with shorter distances between nodes, to increase the resolution.

Calibration of the radial-flow model was achieved by matching simulated drawdown and recovery data with observed data. The resultant suite of values represents a nonunique solution; that is, other combinations of input data could simulate drawdowns that match the observed drawdowns equally well. The results can be considered reliable, however, if the input values are realistic and if the dimensions and structure of the aquifer are accurately represented in the model grid. The structure of the grid can be altered if needed, as long as the changes are within reason and are supported by field evidence.

\section{Examples from Selected Hydrogeologic Settings}

Aquifer tests were performed in two of the six hydrogeologic settings. The test sites were in (1) the freshwater-lens setting at Long Springs Road in Southampton on the South Fork-an upper glacial (unconfined) and a Magothy (confined) test, and (2) the south-shore confined setting at Thomas Street in Bay Shore. Results of the aquifer tests were compared with the range of values reported in the literature.

\section{Freshwater-Lens Setting}

The freshwater-lens site is at the SCWA pumping station wellfield on the east side of Long Springs Road in Southampton. The freshwater lens is within the upper glacial and Magothy aquifers (fig. 6). Conditions within the Magothy range from unconfined to confined as a result of numerous clayey and silty layers. The degree of confinement increases with depth.

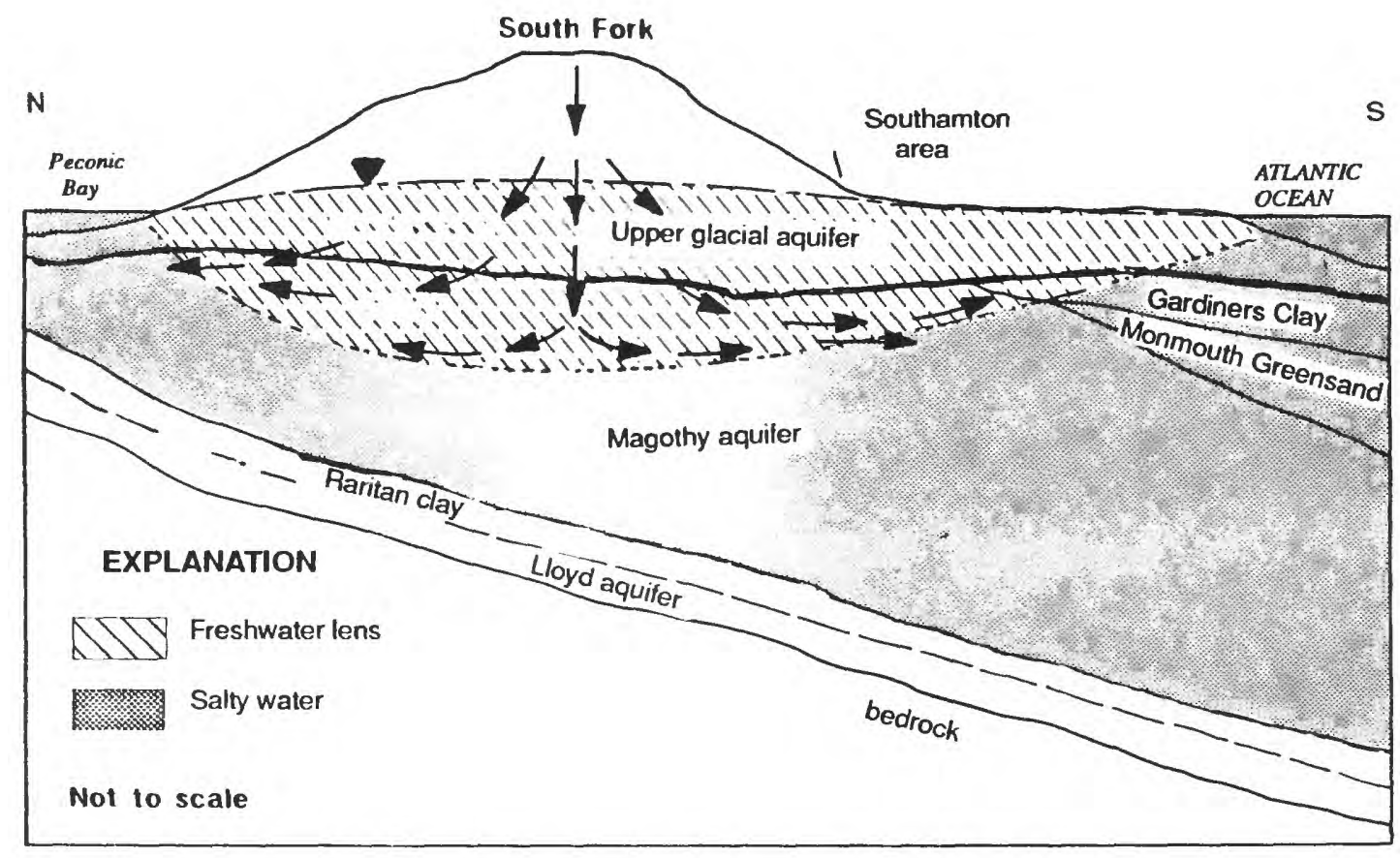

Figure 6. Generalized hydrologic section of the South Fork of Long Island, N.Y., showing hydrologic units, position of freshwater lens, and ground-water-flow patterns typical of the area near Long Springs Road pumping center, Southampton. 


\section{Local Hydrogeology}

The hydrogeologic units on the South Fork are generally similar to those on the rest of Long Island; a typical north-south vertical section of the South Fork (Nemickas and Koszalka, 1982) is shown in figure 6. This hydrogeologic setting differs from those on the Suffolk County mainland in that the ground-water systems are bounded at depth by a freshwater/saltwater interface.

At the Southampton site, the upper glacial aquifer generally consists of outwash deposits of fine to coarse cross-bedded sand, and the Magothy aquifer generally consists of stratified deposits of clay, silt, and fine to medium sand. Although some small areas on the South Fork contain deposits of Monmouth greensand above the Magothy aquifer (Nemickas and Koszalka, 1982), none of these deposits are present at this site, and no Gardiners Clay deposits were identified above the Magothy aquifer at this site.

Ground-water-flow direction and velocity at the Southampton site (fig. 6) are governed by the head distribution and hydraulic properties within the system. A 1984 water-table map by Doriski (1987) indicates (1) a freshwater mound northeast of the Long Springs Road pumping center that coincides roughly with the regional ground-water divide, and (2) a south-southwestward flow gradient of about 0.0003 in the pumping-center vicinity. Data collected for this study in 1987 indicate a similar (0.0008) gradient. The natural horizontal ground-water velocity in the upper glacial aquifer in this area, as calculated from these gradients and an average horizontal hydraulic conductivity of $300 \mathrm{ft} / \mathrm{d}$ (based on estimates of Pluhowski and Kantrowitz, 1964; Fetter, 1971; Nemickas and Koszalka, 1982; and Prince, 1986), and an average porosity of 0.30 (Franke and Cohen, 1972), is $0.3 \mathrm{ft} / \mathrm{d}$ and $0.8 \mathrm{ft} / \mathrm{d}$, respectively. The 1984 potentiometric-surface map of the Magothy aquifer by Doriski (1987) reveals a south-southeastward horizontal gradient of 0.00027 . An average horizontal hydraulic conductivity of $75 \mathrm{ft} / \mathrm{d}$ (from a range of 30 to130 ft/d estimated by Fetter [1971]) and a porosity of 0.3 , gives a natural ground-water velocity of about $0.07 \mathrm{ft} / \mathrm{d}$ in the Magothy aquifer.

\section{Upper Glacial Aquifer Test}

The upper glacial aquifer test at the Long Springs Road pumping station was performed on April 14, 1987; well locations and depths are depicted in figure 7. The upper glacial production well (S17474) was pumped at a rate of $460 \mathrm{gal} / \mathrm{min}$ for 24 hours starting on April 14, and the recovery period was monitored for the next 24 hours.

The upper glacial aquifer test was simulated with the radial-flow model, which had a grid containing 882 nodes and 1,640 elements. The model grid represents the aquifer system from the water table to a depth of $365 \mathrm{ft}$ and horizontally from a 0.5 - $\mathrm{ft}$ radius of the pumping well to an artificial no-flow boundary $5,000 \mathrm{ft}$ away, where no measurable drawdown was expected during the test.

Simulation results indicate that the upper glacial aquifer has a highly conductive upper section (40 ft thick) with a horizontal hydraulic conductivity $\left(K_{h}\right)$ of $400 \mathrm{ft} / \mathrm{d}$ and a vertical hydraulic conductivity $\left(K_{v}\right)$ of $100 \mathrm{ft} / \mathrm{d}$, and a less conductive lower section (130 ft thick) with a $K_{h}$ of $200 \mathrm{ft} / \mathrm{d}$ and $K_{v}$ of $6.1 \mathrm{ft} / \mathrm{d}$. These values are consistent with the range of values reported by Nemickas and Koszalka (1982) for outwash deposits within the upper glacial aquifer $(200$ to $750 \mathrm{ft} / \mathrm{d})$ in the area represented by the freshwater-lens setting.

\section{Magothy Aquifer Test}

The Magothy aquifer test was performed at the Long Springs Road pumping station on April 9, 1987; well locations and depths are depicted in figure 8 . The Magothy production well (S67819) was pumped at a rate of $550 \mathrm{gal} / \mathrm{min}$ for 24 hours, and the recovery period was monitored for the next 120 hours.

Numerical simulation of the Magothy aquifer test was performed with the same grid as for the upper glacial aquifer test. Simulation results indicate:

- an upper glacial aquifer section $20 \mathrm{ft}$ thick

$\left(\mathrm{K}_{h}=400 \mathrm{ft} / \mathrm{d}, \mathrm{K}_{v}=100 \mathrm{ft} / \mathrm{d}\right)$,

- an underlying upper glacial section $145 \mathrm{ft}$ thick

$\left(\mathrm{K}_{h}=300 \mathrm{ft} / \mathrm{d}, \mathrm{K}_{v}=7.5 \mathrm{ft} / \mathrm{d}\right)$,

- an upper Magothy aquifer section $90 \mathrm{ft}$ thick

$\left(K_{h}=80 \mathrm{ft} / \mathrm{d}, K_{v}=3 \mathrm{ft} / \mathrm{d}\right)$,

- a 30 -ft thick clay unit within the Magothy aquifer

$\left(K_{h}=1 \mathrm{ft} / \mathrm{d}, K_{v}=0.2 \mathrm{ft} / \mathrm{d}\right)$, and

- a lower Magothy aquifer section $80 \mathrm{ft}$ thick

(same hydraulic values as upper Magothy).

These values are consistent with the range reported for the Magothy aquifer ( 31 to $134 \mathrm{ft} / \mathrm{d}$ ) by Fetter (1971) for the area represented by the freshwater-lens setting. 

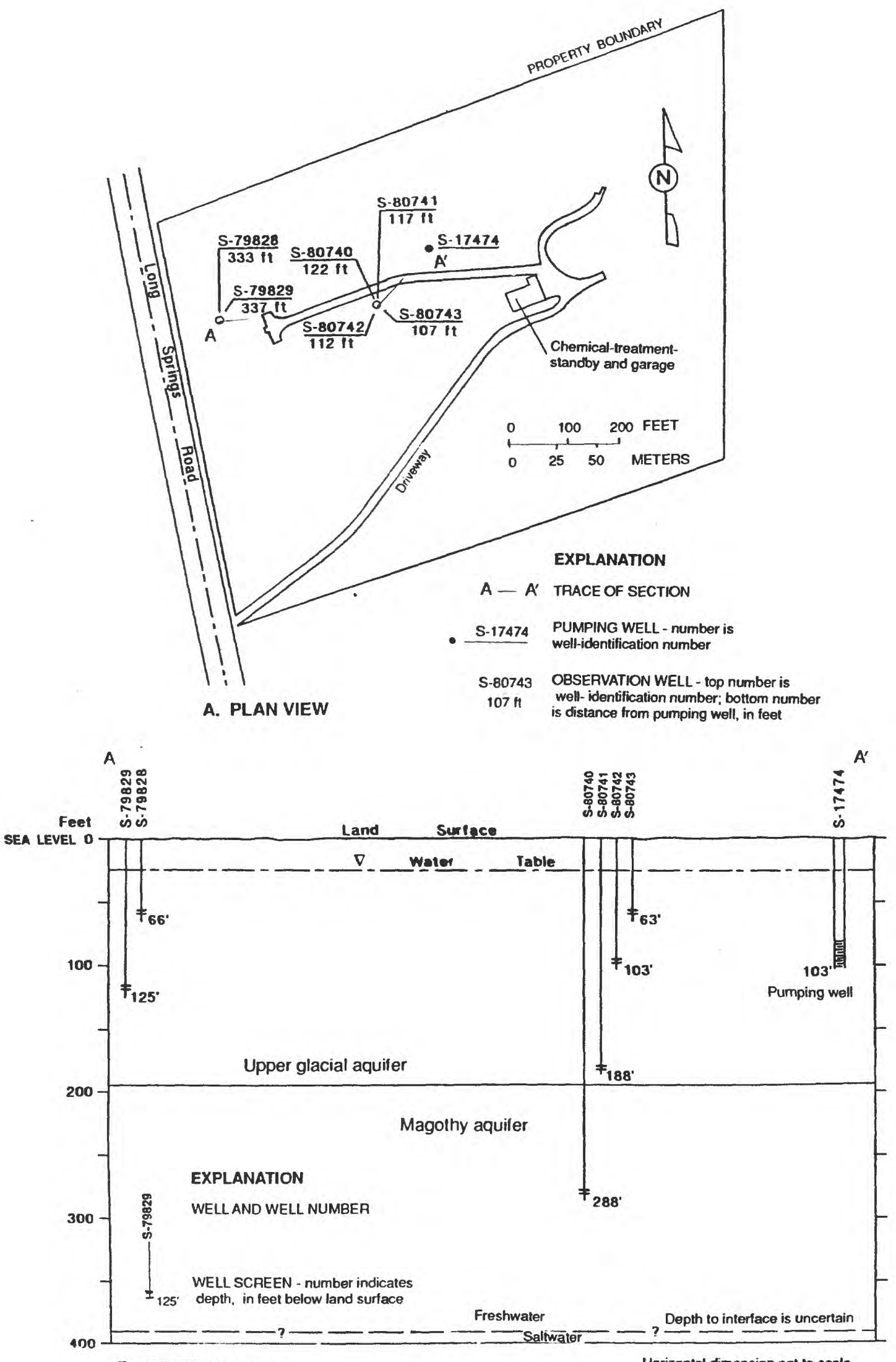

B. VERTICAL SECTION

Horizontal dimension not to scale

Figure 7. Upper glacial aquifer-test setup at Long Springs Road pumping center, Southampton, N.Y. A. Plan view. B. Vertical section. 


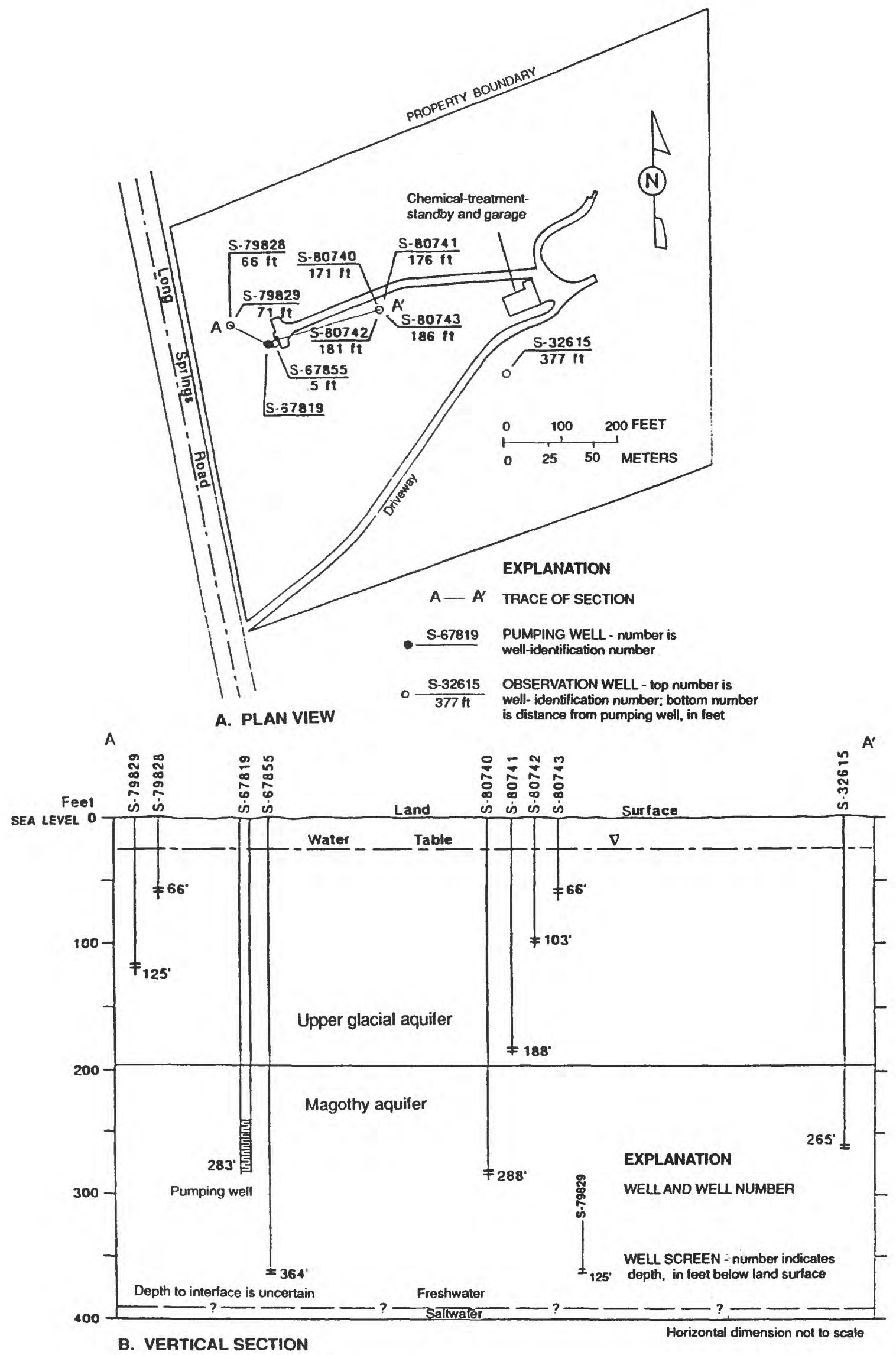

Figure 8. Magothy aquifer-test setup at Long Springs Road pumping center, Southampton, N.Y.

A. Plan view. B. Vertical section. 


\section{South-Shore Confined Setting}

The south-shore confined-aquifer site is at the SCWA pumping station wellfield on Thomas Street in Bay Shore. This setting is within the Magothy aquifer, and the degree of confinement was accounted for in the approach selected for the aquifer-test analysis.

\section{Local Hydrogeology}

The hydrogeology of the south-shore confined setting at the Bay Shore site is similar to that found elsewhere in the Magothy aquifer on the southern shore; a typical north-south section through this area (Smolensky and others, 1989) is shown in figure 9. The Magothy aquifer generally consists of stratified deposits of clay, silt, and fine to medium sand, and is about $1,000 \mathrm{ft}$ thick in the study area (Jensen and Soren, 1974). It is confined by the Gardiners Clay throughout the study area (as deter- mined from wells augured for this study, from coring, and from available well logs). The finegrained deposits of Gardiners Clay are estimated to be from 10 to $15 \mathrm{ft}$ thick within the study area, although the greatest thickness of clay penetrated during well drilling was only about $1 \mathrm{ft}$. Although some areas along the southern shore of Suffolk County typically contain deposits of the Monmouth Greensand above the Magothy aquifer (Smolensky and others, 1989), none of these deposits are present at this site.

Despite the lack of a thick clay sequence in the Gardiners Clay at the Bay Shore site, this unit is an effective confining unit, even where it is only a few feet thick. Evidence for this is the lack of any measurable drawdown in an upper glacial monitoring well (S91 149) during the shallow Magothy aquifer test at this site. This well is only $60 \mathrm{ft}$ from a Magothy production well that was pumping about $785 \mathrm{gal} / \mathrm{min}$ for 24 hours.

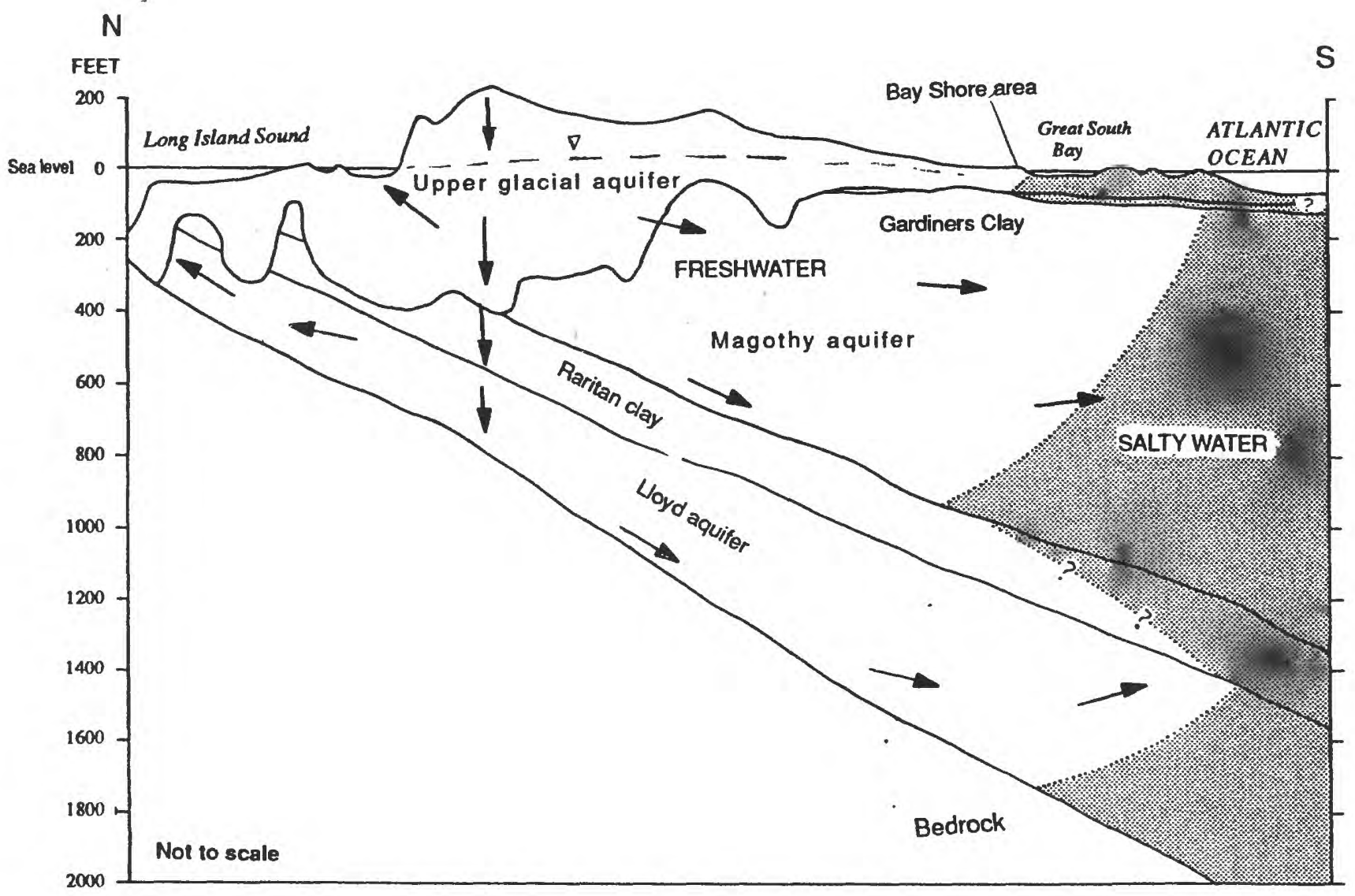

Figure 9. Generalized hydrologic section of the Bay Shore area of Long Island, N.Y., showing hydrologic units, freshwater/saltwater interface, and typical ground-water-flow patterns. (Modified from Smolensky and others, 1989, sheet 1.) 


\section{Magothy Aquifer-Test}

The Magothy aquifer test at the Thomas Street pumping station was performed on April 27, 1989. (Well locations and depths are depicted in fig. 10.) The Magothy production well (S46345) was pumped at a rate of $1,275 \mathrm{gal} / \mathrm{min}$ for 24 hours, and the recovery period was monitored for the next 24 hours.

The Magothy aquifer test was simulated by the numerical radial-flow model with a grid containing 703 nodes and 1,296 elements. The model grid represents a section from the water table to a depth of $1,000 \mathrm{ft}$ and extends from a $0.5-\mathrm{ft}$ radius of the pumping well to an artificial no-flow boundary 5,000 $\mathrm{ft}$ away, where no measurable drawdown was expected during the test. The model included the upper glacial aquifer to allow evaluation of its response to the Magothy aquifer test. As expected, the absence of simulated drawdowns in the upper glacial aquifer confirmed that the pumping stresses did not propagate upward through the Gardiners Clay. The model was insensitive to changes in hydraulic properties specified for the upper glacial aquifer; therefore, these values are not reported. Simulation results indicate a 15 -ft-thick section of Gardiners Clay confining unit at 75 to $90 \mathrm{ft}$ below the water table $\left(K_{h}=0.01 \mathrm{ft} / \mathrm{d}, K_{v}=0.001 \mathrm{ft} / \mathrm{d}\right.$, where $S_{s}=1 \times 10^{-5}$, underlain by the Magothy aquifer $\left(K_{h}=65 \mathrm{ft} / \mathrm{d}, K_{v}=1.0 \mathrm{ft} / \mathrm{d}\right)$. These values are consistent with the range of values reported by Pluhowski and Kantrowitz (1964) for the Magothy aquifer (54 to $161 \mathrm{ft} / \mathrm{d}$ ) in the area represented by the south-shore confined setting.

\section{SUMMARY AND CONCLUSIONS}

Suffolk County was divided into six hydrogeologic settings, on the basis of available data, such that ground-water movement could be assumed to be relatively uniform within each setting and that an aquifer test performed in any of these settings could be expected to yield hydraulic conductivity values that are representative of the entire setting and within the range of published values. This provides a basis for the premise that the hydraulic properties for a given hydrogeologic setting can be derived from relatively few aquifer tests in that setting. The six settings defined are shallow unconfined, shallow confined, south-shore confined, deep Magothy confined, deep Lloyd confined, and freshwater lens.

Two sites were selected for aquifer-test analysis-one at a pumping station at Long Springs Road in Southampton that represents a freshwater-lens setting, and the other at a pumping station at Thomas Street in Bay Shore that represents a southshore confined-aquifer setting. The data from the aquifer tests at these sites were analyzed through analytical and graphical techniques and by a numerical radial-flow model. Numerical models are the most accurate means of analyzing aquifer properties because they avoid the limitations inherent to analytical and graphical methods. Data from additional aquifer tests in hydrogeologic settings lacking sufficient data could decrease the uncertainty in this classification system. 

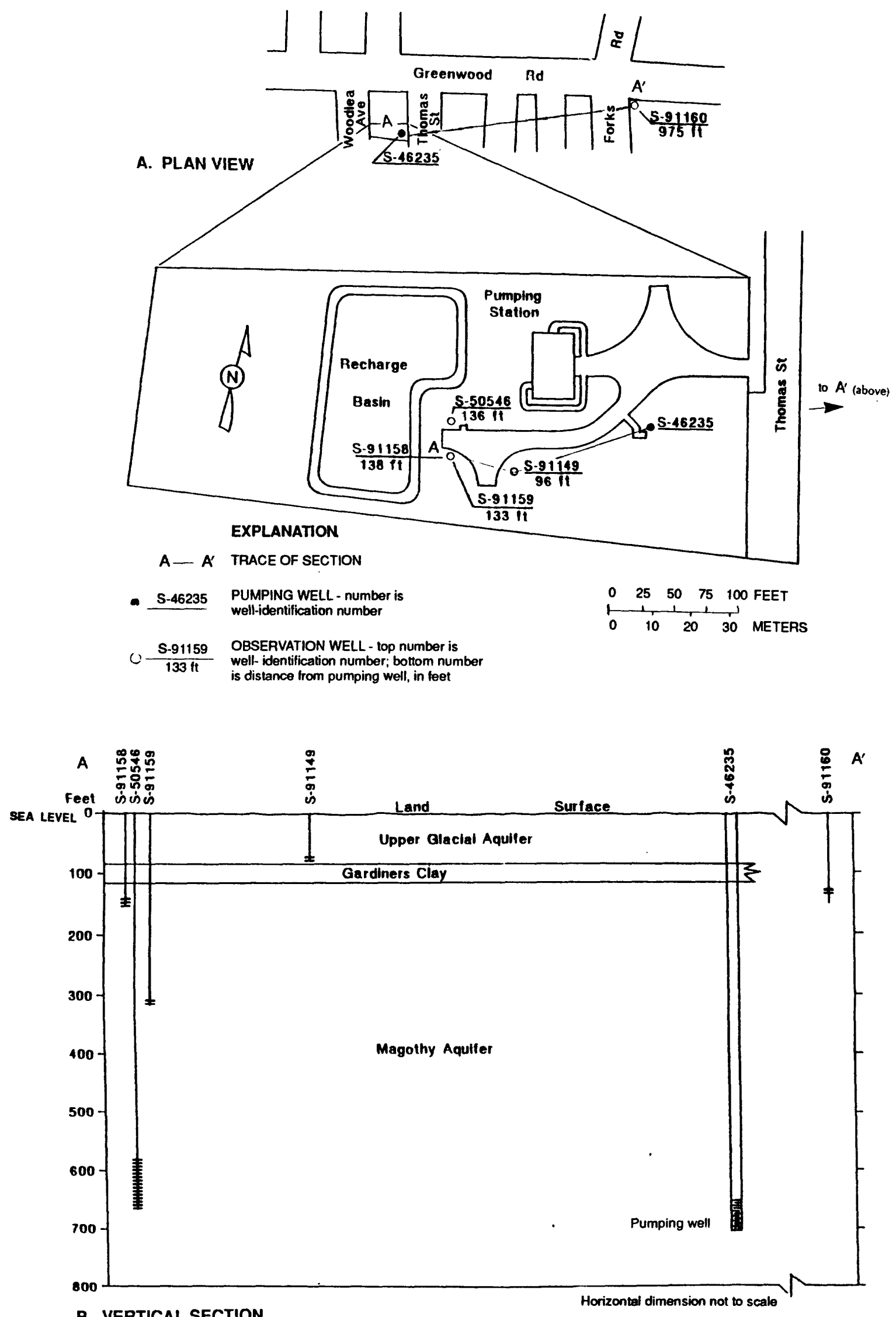

B. VERTICAL SECTION

Figure 10. Magothy aquifer-test setup at Thomas Street pumping center, Bay Shore, N.Y. (Location is shown in fig. 1.) A. Plan view. B. Vertical section. 


\section{REFERENCES CITED}

Bentall, Ray [compiler], 1963, Methods of determining permeability, transmissibility, and drawdown: U.S. Geological Survey Water-Supply Paper 1536-I, p. 245-247.

Bohn-Buxton, D.E., Buxton, H.T., and Eagen, V.K., 1996, Simulation of ground-water flow paths and traveltime in relation to tritium and aldicarb concentrations in the upper glacial aquifer on the North Fork, Long Island, New York: U.S. Geological Survey Open-File Report 95-761, 36 p.

Boulton, N.S., 1963, Analysis of data from non-equilibrium pumping tests allowing for delayed yield from storage: Institute of Civil Engineers Proceedings., v. 26 , p. $469-482$.

Buxton, H.T., Soren, Julian, Posner, Alex, and Shernoff, P.K., 1981, Reconnaissance of the ground-water resources of Kings and Queens Counties, New York: U.S. Geological Survey Open-File Report 81-1186, $64 \mathrm{p}$.

Cohen, Philip, Franke, O.L., and Foxworthy, B.L., 1968, An atlas of Long Island's water resources: New York State Water Resources Commission Bulletin 62, $117 \mathrm{p}$.

Cooper, H.H., Jr., 1963, Type curves for nonsteady radial flow in an infinite leaky artesian aquifer, in Bentall, Ray [compiler], Shortcuts and special problems in aquifer tests: U.S. Geological Survey Water-Supply Paper 1545-C, p. C48-C55.

Cooper, H.H., Jr., and Jacob, C.E., 1946, A generalized graphical method for evaluating formation constants and summarizing well-field history: American Geophysical Union Transactions, v. 27, no. 4, p. 526-534.

Doriski, T.P., 1987, Potentiometric surface of the watertable, Magothy, and Lloyd aquifers on Long Island, New York, in 1984: U.S. Geological Survey WaterResources Investigations Report 86-4189, 4 pl., scale $1: 125,000$.

Doriski, T.P., and Wilde-Katz, Franceska, 1983, Geology of the " 20 -foot" clay and Gardiners Clay in southern Nassau and southwestern Suffolk Counties, Long Island, New York: U.S. Geological Survey WaterResources Investigations Report 82-4056, 17 p.

Driscoll, F.G., 1986, Groundwater and wells (2nd ed.): St. Paul, Minn., Johnson Division, Universal Oil Products, $1,089 \mathrm{p}$.

Eckhardt, D.A.V., Flipse, W.J., Jr., and Oaksford, E.T., 1989, Relation between land use and ground-water quality in the upper glacial aquifer in Nassau and Suffolk Counties, Long Island, New York: U.S. Geological Survey Water-Resources Investigations Report 86-4142, 35 p.
Fetter, C.W., Jr., 1971, Hydrogeology of the South Fork of Long Island, New York: Bloomington, Ind., Indiana University, unpublished Ph.D. dissertation, $236 \mathrm{p}$.

Franke, O.L., 1968, Double-mass curve analysis of the effects of sewering on ground-water levels on Long Island, N.Y., in Geological Survey Research 1968: U.S. Geological Survey Professional Paper 600-B, p. B205-B209.

Franke, O.L., and Cohen, Philip, 1972, Regional rates of ground-water movement on Long Island, New York, in Geological Survey Research 1972: U.S. Geological Survey Professional Paper 800-C, p. C271-277.

Franke, O.L., and McClymonds, N.E., 1972, Summary of the hydrologic situation on Long Island, N.Y., as a guide to water-management alternatives: U.S. Geological Survey Professional Paper 627-F, 59 p.

Fuller, M.L., 1914, The geology of Long Island, New York: U.S. Geological Survey Professional Paper 82, $231 \mathrm{p}$.

Garber, M.S., and Sulam, D.J., 1976, Factors affecting declining water levels in a sewered area of Nassau County, New York: U.S. Geological Survey Journal of Research, v. 4, no. 3, p. 255-265.

Isbister, John, 1966, Geology and hydrology of northeastern Nassau County, Long Island, New York: U.S. Geological Survey Water-Supply Paper 1825,89 p.

Jensen, H.M., and Soren, Julian, 1974, Hydrogeology of Suffolk County, Long Island, New York: U.S. Geological Survey Hydrologic Investigation Atlas HA-501, 2 sheets, scale 1:250,000.

Krulikas, R.K., and Koszalka, E.J., 1983, Geologic reconnaissance of an extensive clay unit in north-central Suffolk County, Long Island, New York: U.S. Geological Survey Water-Resources Investigations Report 82-4075, 9 p.

Long Island Lighting Company, 1995, 1995 Long Island Population Survey: Hicksville, N.Y., 38 p.

Lubke, E.R., 1964, Hydrogeology of the HuntingtonSmithtown area, Suffolk County, New York: U.S. Geological Survey Water-Supply Paper 1669-D, $68 \mathrm{p}$.

Lusczynski, N.J., and Swarzenski, W.V., 1966, Saltwater encroachment in southern Nassau and southeastern Queens Counties, Long Island, New York: U.S. Geological Survey Water-Supply Paper 1613-F, $76 \mathrm{p}$.

McClymonds, N.E., and Franke, O.L., 1972, Water-transmitting properties of aquifers on Long Island, N.Y.: U.S. Geological Survey Professional Paper 627-E, $24 \mathrm{p}$.

McNew, E.R., and Arav, Sara, 1995, Surface geophysical surveys of the freshwater-saltwater interface in a coastal area of Long Island, New York: Ground Water, v. 33 , no. 4 , p. 615-626. 
Miller, J.F., and Frederick, R.H., 1969, The precipitation regime of Long Island, New York: U.S. Geological Survey Professional Paper 627-A, 21 p.

Nemickas, Bronius and Koszalka, E.J., 1982, Geohydrologic appraisal of water resources of the South Fork, Long Island, New York: U.S. Geological Survey Water-Supply Paper 2073, 55 p.

Nemickas, Bronius, Mallard, G.E., and Reilly, T.E., 1989, Availability and historical development of groundwater resources of Long Island, New York-an introduction: U.S. Geological Survey Water-Resources Investigations Report 88-4113, 43 p.

Neuman, S.P., 1974, Effect of partial penetration on flow in unconfined aquifers considering delayed gravity response: Water Resources Research, v. 10, no. 2, p. 303-312.

Pluhowski, E.J., and Kantrowitz, I.H., 1964, Hydrology of the Babylon-Islip area, Suffolk County, Long Island, N.Y.: U.S. Geological Survey Water-Supply Paper 1768, $119 \mathrm{p}$.

Pluhowski, E.J., and Spinello, A.G., 1978, Impact of sewerage systems on stream base flow and groundwater recharge on Long Island, New York: U.S. Geological Survey Journal of Research, v. 6, no. 2, p. 263-271.

Prince, K.R., 1986, Ground-water assessment of the Montauk area, Long Island, New York: U.S. Geological Survey Water-Resources Investigations Report 85-4013, 103 p.

Prince, K.R., Franke, O.L., and Reilly, T.E., 1988. Quantitative assessment of the shallow ground-water flow system associated with Connetquot Brook. Long Island, New York: U.S. Geological Survey WaterSupply Paper 2309, 28 p.

Reilly, T.E., 1984, A Galerkin finite-element flow model to predict the transient response of a radially symmetric aquifer: U.S. Geological Survey Watcr-Supply Paper 2198, 33 p.
Smolensky, D.A., Buxton, H.T., and Shernoff, P.K., 1989, Hydrogeologic framework of Long Island, New York: U.S. Geological Survey Hydrologic Investigations Atlas HA-709, 3 sheets, scale $1: 250,000$.

Soren, Julian, 1971, Ground-water and geohydrologic conditions in Queens County, Long Island, N.Y.: U.S. Geological Survey Water-Supply Paper 2001-A, $39 \mathrm{p}$.

Soren, Julian, and Stelz, W.G., 1984, Aldicarb-pesticide contamination of ground water in eastern Suffolk County, Long Island, New York: U.S. Geological Survey Water-Resources Investigations Report 84-4251, 34 p.

Stallman, R.W., 1965, Aquifer-test design, observation and data analysis: Techniques of Water-Resources Investigations of the U.S. Geological Survey, book 3, chap. v, $26 \mathrm{p}$.

Sulam, D.J., 1979, Analysis of changes in ground-water levels in a sewered and an unsewered area of Nassau County, Long Island, New York: Ground Water, v. 17 , no. 5, p. 446-455.

Suter, Russell, deLaguna, Wallace, and Perlmutter, N.M., 1949, Mapping of geologic formations and aquifers of Long Island, New York: New York State Water Power and Control Commission Bulletin GW-18, $212 \mathrm{p}$.

Theis, C.V., 1935, The relation between the lowering of the piezometric surface and the rate and duration of discharge of a well using ground-water storage: American Geophysical Union Transactions, v. 16, p. 519-524.

Warren, M.A., deLaguna, Wallace, and Lusczynski, N.J., 1968, Hydrology of Brookhaven National Laboratory and vicinity, Suffolk County, New York: U.S. Geological Survey Bulletin 1156-C, 127 p. 